\title{
A CASE OF INFILTRATING LOBULAR CARCINOMA OF THE BREAST WITH GASTRIC METASTASIS 22 YEARS AFTER INITIAL SURGERY
}

\author{
Mohammad Hanafiah ${ }^{1,2}$, Sabrilhakim Sidek ${ }^{2}$, Soo Fin Low ${ }^{3}$ and Chai Soon Ngiu ${ }^{4}$ \\ ${ }^{1}$ Radiology Department, Sunway Medical Centre, Bandar Sunway, Selangor, Malaysia; \\ ${ }^{2}$ Department of Radiology, Faculty of Medicine, Universiti Teknologi MARA, Sungai Buloh Campus, \\ Selangor, Malaysia; \\ ${ }^{3}$ Radiology Department, Faculty of Medicine, Universiti Kebangsaan Malaysia, Kuala Lumpur, Malaysia; \\ ${ }^{4}$ Gastroenterology Department, Faculty of Medicine, Universiti Kebangsaan Malaysia, Kuala Lumpur, Malaysia
}

SUMMARY - Gastric metastasis from breast carcinoma is uncommon and rarely encountered in our daily practice. We report a case of late gastric metastasis from previous infiltrating lobular carcinoma of the breast. The patient had extended disease-free interval of 22 years prior to metastasis. Gastroscopy and fluoroscopy showed changes appearing like linitis plastica of the body of the stomach. Computed tomography of the thorax and abdomen demonstrated pulmonary metastasis and mediastinal lymphadenopathy. Biopsy of the mediastinal lymph node and stomach lesion confirmed metastatic adenocarcinoma from breast carcinoma based on immunohistochemistry staining. Immunohistochemistry staining of both specimens revealed strong positivity for cytokeratin 7 and negative for cytokeratin 20.

Key words: Gastric metastasis; Linitis plastica; Breast carcinoma; Computed tomography; Barium meal

\section{Introduction}

Breast carcinoma is the most common tumor in women ${ }^{1}$. Breast carcinoma commonly metastasizes to local and distant lymph nodes, lung, bone, brain and liver ${ }^{2}$. Gastrointestinal (GI) metastasis from breast carcinoma is rare but a well-described entity in clinical practice; however, the incidence in autopsy series varied from $8 \%$ to $35 \%{ }^{3}$. The signs and symptoms of gastric metastases are nonspecific. They include early satiety, nausea and vomiting, epigastric pain, and weight loss.

Stomach metastasis and primary gastric carcinoma are indistinguishable based on the clinical ground, en-

Correspondence to: Sabrilhakim Sidek, MRad, Department of Radiology, Faculty of Medicine, Universiti Teknologi MARA, Sungai Buloh Campus, Jalan Hospital, 47000 Selangor, Malaysia

E-mail: bhkimy_7@hotmail.com, sabrilhakim@salam.uitm.edu.my Received June 10, 2016, accepted May 31, 2017 doscopy, radiology and histology. Immunohistochemical staining is crucial to confirm the diagnosis. The survival rate in patients with breast carcinoma and gastric metastasis is $23 \%$ at two years, with a median survival of ten months ${ }^{4}$. Lobular subtype, positive estrogen receptor (ER) and simultaneous bone metastases favor the prognosis ${ }^{4}$.

In this case report, we describe the gastroscopic and radiological appearances of gastric metastasis while highlighting an example of very late gastric metastasis (more than 20 years) from breast carcinoma.

\section{Case Report}

A 71-year-old woman presented with hoarseness of voice, loss of weight and early satiety for six weeks. She revealed a background history of left breast infiltrating lobular carcinoma that had been diagnosed 22 years before. At that time, she underwent left mastec- 


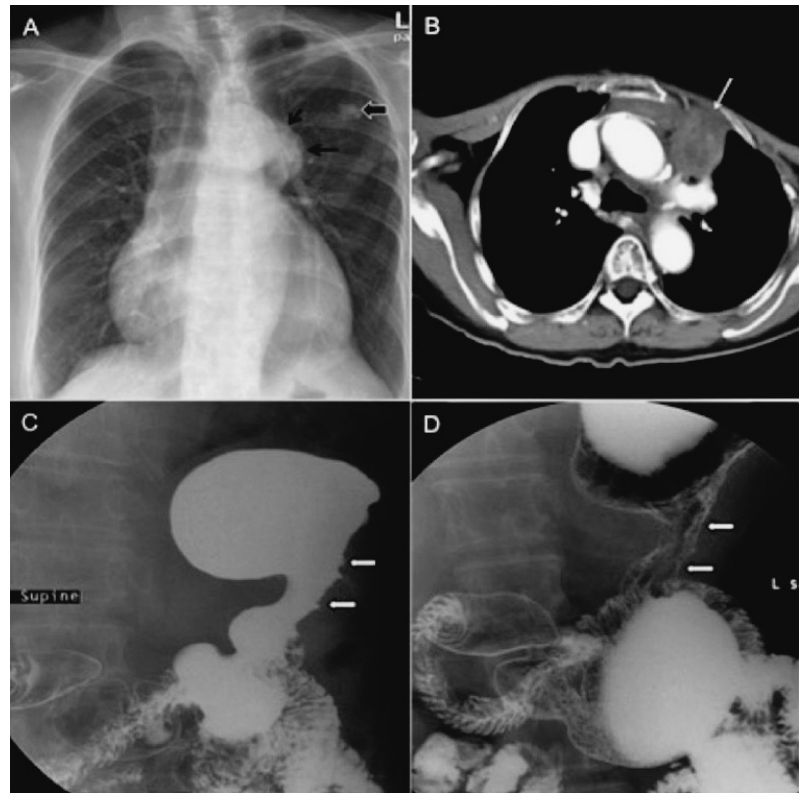

Fig. 1. Chest radiograph $(A)$ demonstrates an anterior mediastinal mass (black thin arrow). Incidental finding of benign calcified lesion from the overlying rib (black thick arrow). Axial computed tomography of the thorax (B) shows anterior mediastinal lymphadenopathy (white arrow). Barium meal ( $C$ and $D)$ demonstrates non-distensible body of the stomach with irregular mucosal outline.

tomy and axillary clearance. She also completed courses of chemotherapy and radiotherapy. Her past routine surveillance check-ups were unremarkable until the current presentation. On arrival, she appeared frail and cachexic. Physical examination was notable for right supraclavicular lymphadenopathy. Otherwise, the inspection and palpation of the breast, axilla and abdomen revealed no significant findings.

In view of voice hoarseness, flexible laryngoscopy was performed and it demonstrated left vocal cord palsy with no associated pharyngeal or laryngeal mass. Chest radiograph showed a lobulated left-sided mediastinal mass projected over the arch of aorta (Fig. 1A). The presence of 'hilum overlay sign' and preserved silhouette of the adjacent aortic arch and descending aorta indicated that the mediastinal mass was anteriorly located.

Gastroscopy was performed and revealed a poorly distended stomach with irregular wall thickening (Fig. 2). Due to remote previous history of breast carcinoma, secondary deposits to the stomach, lung and

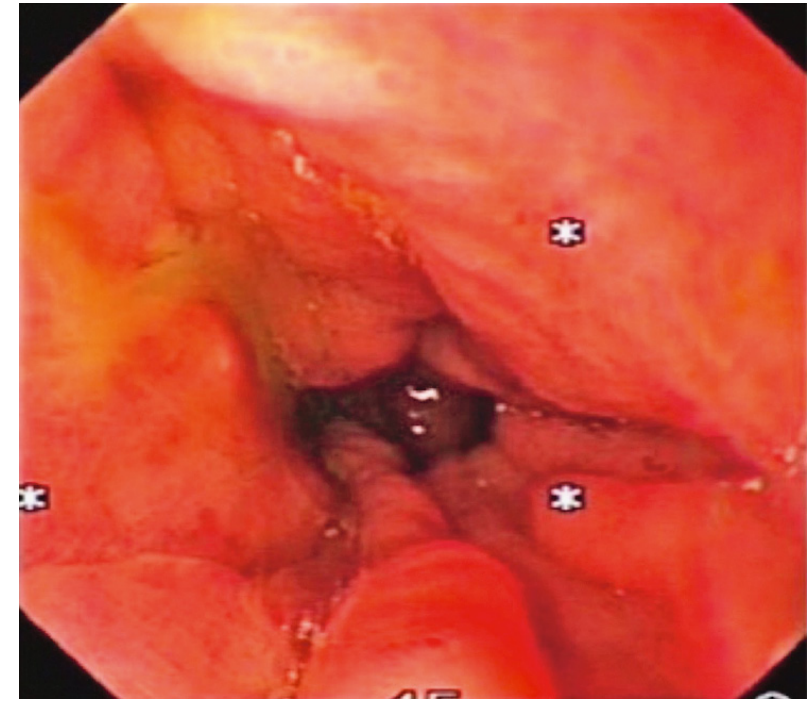

Fig. 2. Gastroscopic image showing rigid and non-distensible body of the stomach with irregular and thickened mucosal folds.

mediastinal lymph nodes were considered. Primary gastric carcinoma was a differential diagnosis. Gastric biopsy was obtained and histopathologic examination showed multiple fragments of gastric mucosal tissue with irregular spaced glands. There were a few malignant cells with gland formation lined by pleomorphic, hyperchromatic nuclei of high nuclear cytoplasmic ratio. In order to distinguish gastric metastasis from primary gastric carcinoma, immunohistochemistry staining was performed. The examination showed the gastric specimen to be positive for cytokeratin 7 (CK7) and negative for cytokeratin 20 (CK20), confirming the diagnosis of metastatic gastric adenocarcinoma from the breast (Fig. 3). Immunohistochemical staining of the specimen also showed it to be positive for estrogen receptor and progesterone receptor.

Mammography and ultrasound findings of the right breast were unremarkable. Computed tomography (CT) for staging revealed heterogeneously enhancing matted mediastinal lymph nodes in the preaortic region (Fig. 1B), likely to be the culprit for the left vocal cord palsy through involvement of the left recurrent laryngeal nerve. An enlarged right supraclavicular necrotic node was also noted. The body of the stomach was thickened and non-distensible despite administration of oral contrast just before the scan. Histopathologic examination of the specimen obtained from the enlarged mediastinal nodes via $\mathrm{CT}$ 


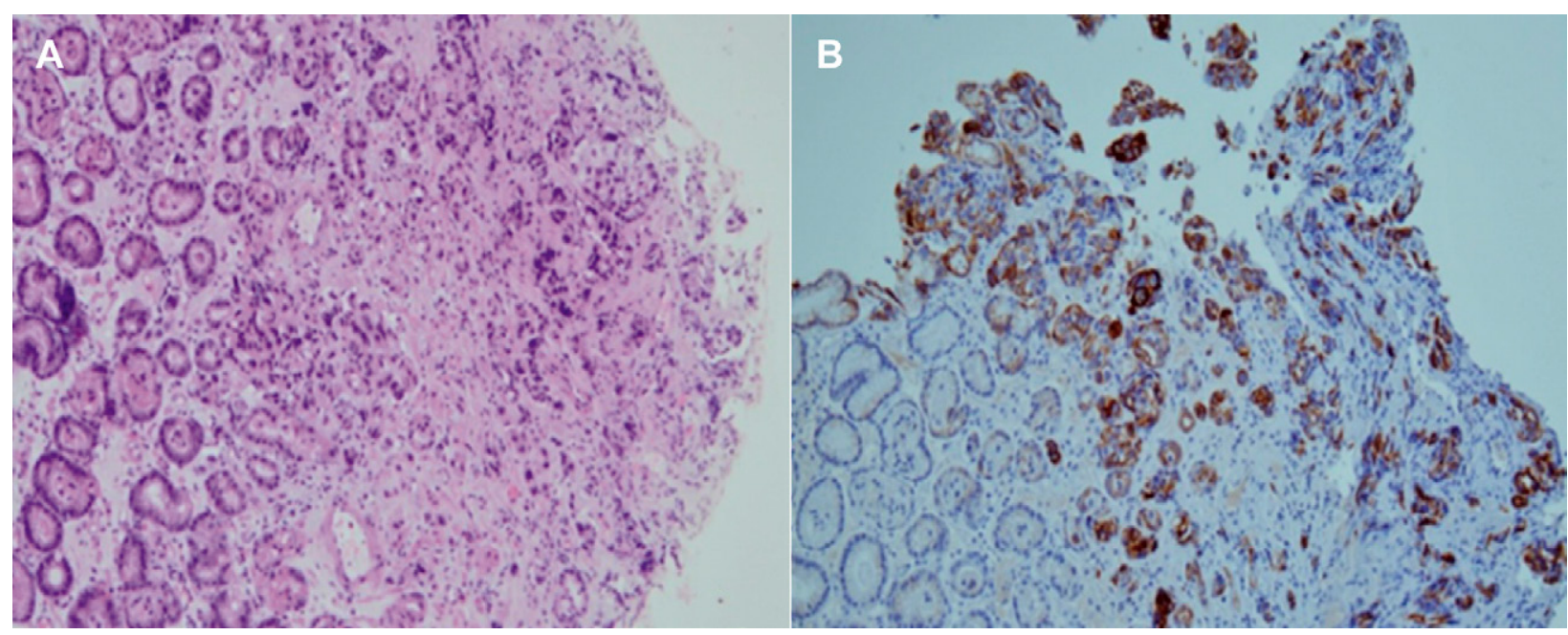

Fig. 3. Histology images show (A) nests of malignant cells with poorly formed gland composed of modest pleomorphic and enlarged nuclei (hematoxylin-eosin stain, X100) which are (B) positive for cytokeratin 7 (immunohistochemical, X100).

guided biopsy showed clusters of malignant cells. Some of the malignant cells showed attempt to structure themselves into glands. Immunohistochemical staining of the specimen showed it to be strongly positive for CK7, estrogen receptor and progesterone receptor, and negative for CK20. Barium meal was used to assess the volume of the stomach and degree of obstruction. The body of the stomach demonstrated irregular mucosal outline, luminal narrowing, rigidity and diminished peristalsis consistent with linitis plastica on fluoroscopy (Fig. 1C, 1D).

Despite receiving chemotherapy, the patient's condition gradually deteriorated with further dissemination of metastases to the liver and bones. She finally succumbed to death after two years of palliative care.

\section{Discussion and Conclusion}

Breast carcinoma with late metastasis to the GI tract is rare. In a surgical series, breast cancer represented $8 \%$ of secondary metastatic malignancies of the GI tract 5 . Unlike ductal carcinoma, lobular carcinoma has a higher tendency to metastasize to the GI tract and peritoneum, and this may be associated with the presence of discohesive small cells, a phenotypic trait that characterizes lobular carcinoma ${ }^{6}$. In addition, late development of metastatic disease in unique anatomic locations is a known characteristic of lobular carcinoma ${ }^{7}$. GI metastases in patients with lobular breast carcinoma usually present 5 years after the initial diagnosis ${ }^{7}$. The mean diagnosis-to-metastasis interval is 7 years in women with lobular breast carcinoma and subsequent GI $\operatorname{spread}^{8}$. In the present case, the disease-free interval was 22 years after the initial diagnosis and, to the best of our knowledge, this is the longest interval being reported in the English literature. Routes of gastric metastasis include hematogenous spread, lymphatic spread, and direct tumor invasion. Breast cancer cells may show discordance between the primary and metastatic lesions, particularly in receptor status ${ }^{9}$. Furthermore, invasive lobular carcinoma at original diagnosis may demonstrate development into mixed invasive lobular/ductal type in $5 \%$ of the cases of GI metastasis ${ }^{10}$.

The most frequent endoscopic and radiographic finding of gastric metastasis is diffuse intramural infiltration ${ }^{11}$. Based on autopsy result, lobular breast carcinoma tends to infiltrate the stomach diffusely, giving rise to linitis plastica, and in contrast, infiltrating ductal carcinoma is usually manifested as nodular gastric masses $^{2}$. In general, radiological imaging and gastric endoscopy are unable to distinguish primary gastric carcinoma from gastric metastasis due to their nonspecific features. In the present case, gastroscopy and barium meal showed the most common type of gastric involvement appearance (i.e. linitis plastica). It is characterized by narrowing of the stomach lumen, rigidity, and diminished peristalsis. Histologic manifestation is also nonspecific as the presence of signet ring cells is seen in both primary gastric carcinoma and gastric metastasis from lobular breast carcinoma. 
Immunohistochemical staining is recommended to distinguish gastric metastasis from primary gastric carcinoma. Immunohistochemical staining is able to determine the presence of cellular markers such as estrogen receptor, progesterone receptor, and CK7. Estrogen receptor and progesterone receptor are found in hormone dependent tumor, and their presence will favor the diagnosis of breast metastasis ${ }^{12}$. However, estrogen receptor is positive in $23 \%$ of primary gastric carcinoma cases ${ }^{13}$. As a result, positive estrogen receptor alone may not be able to distinguish primary gastric carcinoma from metastasis. A more recent paper showed estrogen receptor, progesterone receptor and CK7 to be highly specific for metastatic breast carcinoma, and CK20 to be highly specific for primary gastric carcinoma ${ }^{14}$.

Making the diagnosis of breast carcinoma with metastasis to the stomach is difficult especially in extended disease-free interval. Despite its rarity, in patients with a history of breast cancer, a high index of suspicion of potential breast cancer metastasis to the stomach is required when new GI symptoms develop or primary gastric cancer is diagnosed.

In conclusion, we propose careful life-long followup of patients with background history of breast cancer, particularly of lobular subtype, as recurrence and metastases can develop after a prolonged disease-free interval. A combination of histopathologic analysis and immunohistochemical staining of gastric biopsy are essential to ascertain the diagnosis and choose appropriate treatment.

\section{References}

1. Žitnjak D, Soldić Ž, Kust D, Bolanča A, Kusić Z. Demographic and clinicopathologic features of patients with primary breast cancer treated between 1997 and 2010: a single institution experience. Acta Clin Croat. 2015 Sep;54(3):295-302.

2. Yoon SK, Dong WR, Chung HL. Peritoneal and gastric metastasis from invasive lobular breast carcinoma: a case report. KMJ Kosin Med J. 2015;30(1):87-92, http://dx.doi.org/10.7180/ kmj.2015.30.1.87

3. Ambroggi M, Stroppa EM, Mordenti P, Biasini C, Zangrandi A, Michieletti E, et al. Metastatic breast cancer to the gastrointestinal tract: report of five cases and review of the literature.
Int J Breast Cancer. 2012;439023, http://dx.doi.org/10.1155/ 2012/439023

4. Taal BG, Peterse H, Boot H. Clinical presentation, endoscopic features, and treatment of gastric metastases from breast carcinoma. Cancer. 2000;89(11):2214-21, http://dx.doi.org/10. 1002/1097-0142(20001201)89:11<2214::AID-CNCR9>3.0. $\mathrm{CO} ; 2-\mathrm{D}$

5. Washington K, McDonagh D. Secondary tumors of the gastrointestinal tract: surgical pathologic findings and comparison with autopsy survey. Mod Pathol. 1995;8(4):427-33.

6. Tan L, Piao Y, Liu Z, Han T, Song F, Gao F, et al. Breast cancer metastasis to the stomach confirmed using gastroscopy: a case report. Oncol Lett. 2014;8(3):1205-7, http://dx.doi.org/10. 3892/ol.2014.2260

7. Carcoforo P, Raiji MT, Langan RC, Lanzara S, Portinari M, Maestroni $\mathrm{U}$, et al. Infiltrating lobular carcinoma of the breast presenting as gastrointestinal obstruction: a mini review. J Cancer. 2012;3:328-32, http://dx.doi.org/10.7150/jca.4735

8. Mahmud N, Ford JM, Longacre TA, Parent R, Norton JA. Metastatic lobular breast carcinoma mimicking primary signet ring adenocarcinoma in a patient with a suspected CDH1 mutation. J Clin Oncol. 2015;33(4):e19-21, http://dx.doi.org/10. 1200/JCO.2013.49.1159

9. Broom RJ, Tang PA, Simmons C, Bordeleau L, Mulligan AM, O'Malley FP, et al. Changes in estrogen receptor, progesterone receptor and Her-2/neu status with time: discordance rates between primary and metastatic breast cancer. Anticancer Res. 2009 May 1;29(5):1557-62.

10. Switzer N, Lim A, Du L, Al-Sairafi R, Tonkin K, Schiller D. Case series of 21 patients with extrahepatic metastatic lobular breast carcinoma to the gastrointestinal tract. Cancer Treat Commun. 2015 Dec 31;3:37-43, http://dx.doi.org/10.1016/j. ctrc.2014.11.006

11. Hara F, Kiyoto S, Takabatake D, Takashima S, Aogi K, Ohsumi $\mathrm{S}$, et al. Metastatic breast cancer to the stomach resembling early gastric cancer. Case Rep Oncol. 2010;3(2):142-7, http:// dx.doi.org/10.1159/000313923

12. Miše I, Vučić M, Maričević I, Šokčević M, Čurić-Jurić S. Histologic subtypes of invasive lobular carcinoma in correlation with tumor status and hormone receptors. Acta Clin Croat. 2010 Sep 14;49(3):275-81.

13. Kojima O, Takahashi T, Kawakami S, Uehara Y, Matsui M. Localization of estrogen receptors in gastric cancer using immunohistochemical staining of monoclonal antibody. Cancer. 1991;67(9):2401-6, http://dx.doi.org/10.1002/1097-0142(199 10501)67:9<2401::AID-CNCR2820670931>3.0.CO;2-H

14. O'Connell FP, Wang HH, Odze RD. Utility of immunohistochemistry in distinguishing primary adenocarcinomas from metastatic breast carcinomas in the gastrointestinal tract. Arch Pathol Lab Med. 2005;129(3):338-47, http://dx.doi.org/10. 5858/2005-129-338-UOIIDP 


\section{Sažetak \\ ŽELUČANA METASTAZA INFILTRATIVNOG KARCINOMA DOJKE 22 GODINE NAKON PRVE OPERACIJE - PRIKAZ SLUČAJA}

\section{Hanafiah, S. Sidek, Low Soo Fin i Ngiu Chai Soon}

Metastaze karcinoma dojke u želudac nisu česte i rijetko se vide u svakodnevnoj praksi. Opisujemo slučaj kasne želučane metastaze iz prethodnog infiltrativnog lobularnog karcinoma dojke. Prije nastanka metastaze bolesnica je imala dugotrajno razdoblje bez bolesti od 22 godine. Gastroskopija i fluoroskopija pokazale su promjene poput linitis plastica na tijelu želuca. Kompjutorizirana tomografija prsnog koša i trbuha pokazala je plućnu metastazu i limfadenopatiju. Biopsija limfnog čvora medijastinuma i želučane promjene potvrdila je metastatski adenokarcinom iz karcinoma dojke na osnovi imunohistokemijskog bojanja pri čemu su oba uzorka bila snažno pozitivna na citokeratin 7 i negativna na citokeratin 20 .

Ključne riječi: Želučana metastaza; Linitis plastica; Karcinom dojke; Kompjutorizirana tomografja; Barijeva kaša 